\title{
The Efficiency of Public Higher Education Institutions: A Meta-Analysis ${ }^{1}$
}

\author{
Pavla MIKUŠOVÁ*
}

\begin{abstract}
Measuring the efficiency of public higher education institutions has become a subject of many studies. We analyse these studies using meta-analysis and identify the most commonly adopted inputs and outputs in the DEA and SFA models (e.g. the number of students, graduates, academic staff). Data obtained from these studies were used for meta-regression analysis. We analyse the effect of independent variables (sample size, the number of inputs and outputs, method used, model orientations, returns to scale and to the country) on the average technical efficiency of public higher education institutions. Finally, we use this model to predict the average technical efficiency of the Czech and Slovak public higher education institutions.
\end{abstract}

Keywords: efficiency, higher education, meta-analysis, regression, DEA, SFA

JEL Classification: C21, C67, I23

DOI: https://doi.org/10.31577/ekoncas.2020.09.05

\section{Introduction}

In Europe, funding for higher education comes predominantly from public sources. On average, $77.7 \%$ of the EU-23 tertiary education is funded publicly (for OECD countries, the share stands at 69.9\%). The remaining resources are private. The share of public funding is the highest in the Nordic countries, e.g. 96.6\% in Finland, 96.0\% in Norway or $88.7 \%$ in Sweden. Among the Visegrad

* Pavla MIKUŠOVÁ, University of Economics, Prague, Faculty of Finance and Accounting, Department of Public Finance, W. Churchill Sq. 4, 13067 Prague 3, Czech Republic; e-mail: pavla.mikusova@vse.cz

${ }^{1}$ The paper was prepared as one of the outputs of the research project of the Faculty of Finance and Accounting at the University of Economics, Prague Economic and institutional aspects of public finance registered by the Internal Grant Agency of University of Economics, Prague under the registration number F1/7/2019. 
countries, the lowest share of public funds has Hungary with only $62.9 \%$. On the other hand, the proportion stands at $83.8 \%$ in Poland, 80.2\% in Slovakia and $80.1 \%$ in the Czech Republic (OECD, 2018).

The large share of public funding gives an incentive to focus on the efficiency of public higher education institutions (HEIs). In this respect, the presented study measures technical efficiency. By technical efficiency we understand the ability of a production unit to secure the maximum volume of outputs using the given amount of inputs, respectively, to use the minimum volume of inputs in order to produce the given amount of outputs (Jablonský and Dlouhý, 2004). Technical efficiency can be measured using non-parametric (e.g. DEA, Data Envelopment Analysis) or parametric (e.g. SFA, Stochastic Frontier Analysis) methods. In the domain of the efficiency of HEIs and tertiary education itself, DEA is the most frequently adopted method of measurement, popular mainly for its simplicity. DEA can also be used when the sample size is small. On the other hand, SFA requires a larger sample size and the inputs and outputs used in the model need to be expressed in monetary units (Polouček et al., 2006). For detailed description of the methods see the original work by Charnes, Cooper and Rhodes (1978) and Banker, Charnes and Cooper (1984) for DEA and Meeusen and van den Broeck (1977), Aigner, Lovell and Schmidt (1977) and Battese and Corra (1977) for SFA.

In this paper, we focus on a different approach to the efficiency of public higher education institutions. We do not measure efficiency of any particular HEIs in any given country; instead, we analyse the already existing studies and their data. We use this data to predict the average technical efficiency of public HEIs using meta-regression analysis. The aim of this paper can be split into three questions:

- What are the most commonly adopted inputs and outputs in the DEA and SFA models for measuring of the efficiency of higher education institutions?

- How do the selected variables for meta-regression analysis affect the average efficiency score of higher education institutions?

- What is the predicted average efficiency score of the Czech and Slovak public higher education institutions?

This paper is organised as follows. The literature review is presented in Section 1. Section 2 introduces the adopted methods. Data and the results are presented and discussed in Section 3. Section 4 concludes the analysis.

\section{Literature Review}

Measurement of the efficiency of public higher education institutions has been approached by numerous authors and compiled for different countries. Review of the selected studies is presented below. 
Agasisti and Gralka (2017) measured the efficiency of public HEIs in Italy (52 HEIs in total) and Germany (70 HEIs in total) between 2001 and 2011 using SFA. They divided the efficiency analysis into two parts, namely the short-term and long-term efficiency. The shorter period reflected the efficiency of individual universities in the country. The longer period highlighted in turn the influence of the specific structure of individual universities in the country. When comparing the efficiency of higher education institutions across the two countries, the authors concluded that the difference in efficiency is related to the individual performance of the HEIs and their structure. In conclusion, they find out that the overall level of technical efficiency at Italian HEIs is higher than at universities in Germany.

Coelli et al. (2005) used DEA to measure the efficiency of 36 HEIs in Australia. The analysis was carried out in 1994 and focused on administrative costs. The authors concluded that distance learning students are more expensive in terms of administrative requirements.

Cokgezen (2009) measured the efficiency of universities in Turkey in 2004. The DEA analysis included both type: 47 public and 23 private HEIs. He concluded that Turkish private universities are less efficient than public institutions. Nevertheless, following the inclusion of a quality variable into the model (students' results at the university entrance examinations in 2004), the efficiency values of the private and public universities have converged.

Cuenca (2011) focused on the efficiency of 78 public universities in the Philippines in 2006 - 2009. The efficiency was measured by DEA. The result of the analysis showed that over the period under review, $62 \%$ of the schools improved their efficiency. For further research, it is recommended to look more closely at the analysis of inefficient HEIs and to identify the factors that led to such an outcome.

Daghbashyan (2011) measured the efficiency of Swedish public HEIs using SFA. In this work, he estimated the cost function based on the data for 30 universities from the period 2001 - 2005. Inputs were the number of academic staff, average salary, etc. Outputs were the number of enrolled students (which were further split according to the individual fields: humanities, technical fields and medicine) or the number of PhD students. This study shows that there are differences among universities. Efficiency of the most of them was above average. Only six universities were below the average. During this period, the efficiency of Swedish HEIs has not changed in any way.

Gromov (2017) analysed the efficiency of 120 Russian public HEIs using DEA during the period 2013 - 2015. His research has shown that there is still a room for improvement in the efficiency. Reducing the size of some HEIs would increase their efficiency. 
Johnes (2006) analysed the efficiency of 109 HEIs in England using DEA. He constructed eight models combining nine variables (inputs and outputs) in various ways. The author concludes that the efficiency of English HEIs is high.

Kempkes and Pohl (2007) measured the efficiency of 72 public HEIs in Germany over the period 1998 - 2003. DEA and SFA methods were used. Once the technical efficiency was calculated for each HEI, the authors divided them into northern and eastern German HEIs. They found out that in terms of the overall factor productivity, Eastern public HEIs are better than Western ones. However, in terms of the average technical efficiency, this figure is higher for the Western HEIs.

Maleki, Klumpp and Cuypers (2012) focused on the efficiency of 28 public universities in Germany. They used DEA to analyse the technical efficiency. They created one model, which was input- and output-oriented. Only four universities achieved $100 \%$ technical efficiency. Based on the results, the authors conclude that the output-oriented model is a more appropriate option with regard to an assessment of the education system. At the same time, the choice of such a model orientation is appropriate because of the insufficient supervision of universities and control over some inputs, such as their overall budget.

McMillan and Datta (1998) measured the efficiency of public HEIs in Canada using DEA. They reviewed data for 45 Canadian universities covering the period 1992 - 1993. These universities were split into three groups: comprehensive universities with a medical field, comprehensive universities without a medical field and primarily undergraduate. The total of nine models were created, differing in the combination of inputs (number of faculties, other expenditures, total expenditures, etc.) and outputs (number of graduates, number of $\mathrm{PhD}$ awarded, number of researches performed, etc.). The resulting efficiency of all three groups of universities ranged from $89 \%$ to $98 \%$. Although the resulting efficiency was within this very favourable range, in each group there was one university that was significantly below the average. Despite its shortcomings, the authors described the DEA methodology as very useful. At the same time, they suggest measuring the efficiency of units that are more homogeneous, such as faculties or departments.

Nazarko and Šaparauskas (2014) measured the efficiency of 19 public technical HEIs in Poland in 2011 using DEA. The authors state that the analysis showed, among other things, the usefulness and rationality of using DEA in the higher education sector. The results of the technical efficiency carry important information on the efficiency of the operation of higher education institutions relative to other institutions within a similar field. They also mention that efficiency analysis can be an important stimulus to the growth of education and research quality, it can lead to improved efficiency in public spending and allocation of 
funds, as well as improved management of the higher education. However, the authors also add it is necessary to avoid any hasty conclusions and properly interpret the results of technical efficiency. The correct interpretation of these results requires deep knowledge of the field and great care in formulating any radical conclusions.

Robst (1997) measured the efficiency of 200 US public universities using SFA. He concluded that inefficiencies occur in public universities located in the states whose costs are about $20 \%$ above the estimated frontier. He also found that states with a higher number of students who enrolled for a two-year study score a higher value of efficiency than states with a lower number of such students. He added that large university systems tend to be more efficient than the small ones.

Sav (2016) focused on public American universities (378 HEIs in total) over the period $2004-2013$. The efficiency was measured by SFA. The results of his analysis confirm the view that the government's involvement in financing of the public higher education institutions is important, as it has been shown that any reduction in the state funding of public HEIs causes inefficiencies.

Tochkov, Nenovsky and Tochkov (2012) analysed the technical efficiency of 33 public universities in Bulgaria using DEA. The authors found that public universities are less effective than private universities, especially in the field of teaching. In Bulgaria, a proposal was made to reform the performance-based funding for higher education. It was found that the values of efficiency and allocated subsidies are negatively correlated. On the other hand, a positive correlation was found between the efficiency and cost-efficiency, suggesting that the reform is moving in the right direction.

Tran and Villano (2017) measured the efficiency of 112 public universities in Vietnam. They used DEA and tested the period of 2011 - 2013. It was established that the location, age, ownership and financial capacity have significant effects on the efficiency indicators' mix of the examined universities. In addition to public universities, the authors also calculated the efficiency of private universities. In Vietnam, public universities are more efficient than private universities.

\section{Methodology and Data}

We use meta-analysis and meta-regression analysis to answer the pre-established set of questions. Meta-analysis applies statistical procedures in order to summarise the results of two or more empirical studies that address the same or similar problem. The process of meta-analysis resembles an empirical research. The problem and variables are determined, the data are collected and analysed (Hendl, 2012). 
JSTOR, EconLit, Google Scholar and standard web searches served as the sources for tracing the included studies. A prerequisite for meta-analysis is to search for all the studies on the given topic. However, there are some limitations, including publication bias, identification error, and selection omissions (Hendl, 2012). These limitations were also reflected in the performed meta-analysis. Only studies in English that were freely available or available after login (e.g. JSTOR) were selected. Keywords for the study search were: efficiency, universities, higher education, data envelopment analysis, stochastic frontier, production frontier, cost frontier. In total 126 primary studies were found. Most of them were articles published in scientific journals. Other sources included chapters in books, studies, or working papers.

Studies that did not meet the criteria for meta-regression analysis were excluded from the list. As variables were chosen the average efficiency score, number of units, number of inputs and outputs, model orientation, returns to scale, method of measuring efficiency, and the country (see Table 1). Studies that measured the efficiency of tertiary education among selected countries or departments/faculties, or that did not contain the required data for regression analysis were excluded from the list (e.g. missing information on the orientation of the model, constant or variable returns to scale, unspecified number of inputs and outputs used in the model, inclusion of private higher education institutions). Some primary studies, which included an overview of the resulting efficiency of individual public higher education institutions, lacked an indication of the average efficiency, required for regression analysis. In this case, the average efficiency was calculated, and the studies were included in the regression analysis list.

Table 1

Definitions of Variables

\begin{tabular}{|l|l|l|}
\hline Abbreviation & \multicolumn{1}{|c|}{ Variables } & \multicolumn{1}{c|}{ Definition } \\
\hline EFF & Efficiency & $\begin{array}{l}\text { Average efficiency score of public higher education institutions } \\
\text { (arithmetic mean). }\end{array}$ \\
\hline DMU & $\begin{array}{l}\text { Number of decision } \\
\text { making units }\end{array}$ & $\begin{array}{l}\text { Number of public higher education institutions (HEIs) in primary } \\
\text { studies. }\end{array}$ \\
\hline DIMENSIONS & $\begin{array}{l}\text { Number of inputs } \\
\text { and outputs }\end{array}$ & Number of inputs and outputs used in the model. \\
\hline INPUT_ORT & Used method & $\begin{array}{l}\text { Dummy variable: } 1 \text { if DEA method is used, } \\
\text { 0 if SFA method is used. }\end{array}$ \\
\hline CRS & Returns to scale & $\begin{array}{l}\text { Dummy variable: } 1 \text { if the model is input-oriented, } \\
\text { 0 if the model is output-oriented. }\end{array}$ \\
\hline COUNTRY & Country & $\begin{array}{l}\text { Dummy variable: } 1 \text { if constant returns to scale are used, } \\
\text { Dif variable returns to scale are used. }\end{array}$ \\
\hline
\end{tabular}

Source: Own elaboration. 
In total 38 primary studies were selected for meta-regression analysis. These studies were published from 1997 to 2017 and were from different countries. The list of studies, including the method used to measure the technical efficiency, is given in Table 9 in Appendix. The data set of 402 values (excluding outliers) was extracted from these studies and used in meta-regression analysis. Descriptive statistics of the data set presents Table 2 .

T a b l e 2

Descriptive Statistics of the Data Set

\begin{tabular}{|l|c|c|c|c|c|}
\hline Variables & Minimum & Maximum & Mean & Median & $\begin{array}{c}\text { Standard } \\
\text { deviation }\end{array}$ \\
\hline EFF & 34.1 & 99.96 & 76.645 & 81.4 & 15.049 \\
DMU & 6 & 80 & 47.276 & 54 & 17.037 \\
DIMENSIONS & 2 & 9 & 4.851 & 5 & 1.426 \\
NON_PARA & 0 & 1 & 0.796 & 1 & 0.403 \\
INPUT_ORT & 0 & 1 & 0.338 & 0 & 0.473 \\
CRS & 0 & 1 & 0.371 & 0 & 0.483 \\
COUNTRY & 0 & 1 & 0.841 & 1 & 0.366 \\
\hline
\end{tabular}

Source: Own elaboration.

Correlation analysis shows the relationship between variables (see Table 3).

$\mathrm{T}$ a ble 3

Correlation Analysis

\begin{tabular}{|c|c|c|c|c|c|c|c|}
\hline & $\frac{T}{\mid r}$ & 竞 & $\begin{array}{l}Z_{0}^{n} \\
\sum_{0}^{n} \\
\sum_{0}^{n} \\
0\end{array}$ & 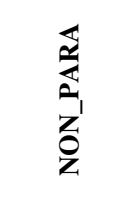 & 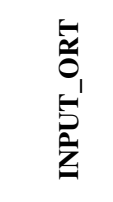 & 结 & 齐 \\
\hline \begin{tabular}{|l|} 
EFF \\
DMU \\
DIMENSIONS \\
NON_PARA \\
INPUT_ORT \\
CRS \\
COUNTRY \\
\end{tabular} & 1.0000 & $\begin{array}{r}-0.2365 \\
1.0000\end{array}$ & $\begin{array}{l}0.1182 \\
0.6058 \\
1.0000\end{array}$ & $\begin{array}{r}0.3850 \\
-0.3344 \\
0.0725 \\
1.0000\end{array}$ & $\begin{array}{r}-0.1617 \\
0.1526 \\
0.0114 \\
-0.5679 \\
1.0000\end{array}$ & $\begin{array}{r}-0.2774 \\
-0.0293 \\
-0.1116 \\
-0.5608 \\
0.4481 \\
1.0000\end{array}$ & $\begin{array}{r}-0.1756 \\
-0.3369 \\
-0.4902 \\
0.0828 \\
-0.2785 \\
-0.1184 \\
1.0000 \\
\end{array}$ \\
\hline
\end{tabular}

Source: Own elaboration.

Log-linear model was chosen for meta-regression analysis in the following form:

$$
\begin{aligned}
& E F F=\beta_{0}+\beta_{1} \cdot \ln (D M U)+\beta_{2} \cdot \ln (\text { DIMENSIONS })+\beta_{3} . N O N_{-} P A R A+ \\
& +\beta_{4} . \text { INPUT_ORT }+\beta_{5} \cdot C R S+\beta_{6} . \text { COUNTRY }+\varepsilon
\end{aligned}
$$

Meta-regression analysis was performed using Ordinary Least Squares (OLS) in $\mathrm{R} . \mathrm{R}$ is a free software environment for statistical computing and graphics (R Core Team, 2017). 


\section{Results and Discussion}

Overview of the most commonly adopted inputs and outputs in the DEA and SFA models of the efficiency of public higher education institutions provides Table 4. As can be seen, the number of students was adopted both as an input and output; the choice depends on what the model stands for (e.g. teaching model).

T a ble 4

The Most Used Inputs and Outputs in the DEA and SFA Models

\begin{tabular}{|l|l|}
\hline Input variables & Output variables \\
\hline Academic staff & Number of students \\
Other employees & Number of graduates \\
Operating costs (in USD) & Total PhD degrees awarded \\
Total expenditure (in USD) & Number of grants \\
Number of students & Number of publications \\
Number of employees & Number of grants (in USD) \\
\hline
\end{tabular}

Source: Own elaboration.

All the variables are quantitative. On the other hand, it is the quality aspect that is essential for tertiary education; the practice shows when two HEIs produce a different number of graduates with the same level of given input variables, this fact does not automatically mean that the HEI which produced fewer graduates is necessarily inefficient. It is therefore appropriate to include also quality indicators into the analysis. However, there is usually a problem with data availability.

Quality is a difficult aspect to quantify and therefore also rarely included in assessment of efficiency. Ball (1985) presented a paper titled "What the hell is quality". Schindler et al. (2015) comment that since then, the definition of quality has not changed much. However, there are studies where authors have attempted to include the aspect of quality in the models using graduation rates, drop-out rates, or average grades (Gralka, 2018).

Using meta-regression analysis, we were able to specify how the selected variables affect the average efficiency score of higher education institutions. Results of meta-regression analysis are presented in Table 5. Adjusted R-squared is 0.4241 and F-statistic is 50.22 (p-value 0.000).

There is heteroscedasticity present in the model (we have used the BreuschPagan test). One solution for dealing with heteroscedasticity is the so-called robust estimation of standard deviation. The standard error estimates of parameters are obtained from the covariation matrix of the parameter vector (Zeileis, 2004).

Signs of the coefficients correspond to our assumptions: increasing number of units (DMU) will lead to a decrease in the average technical efficiency (EFF). Increasing number of inputs and outputs will lead to an increase in EFF. Choosing 
DEA will cause an increase in EFF and choosing SFA will cause a decrease in EFF. A decrease in EFF can also be caused by the choice of the input-oriented model and by the choice of constant returns to scale, which is consistent with the principle of constant returns to scale versus variable returns to scale. If the technical efficiency of the higher education institutions is measured for European countries, it will decrease EFF.

Table 5

Results of Meta-Regression Analysis

\begin{tabular}{|l|c|c|c|}
\hline Variables & Coefficients & Std. error & p-value \\
\hline Intercept & 102.9104 & 5.7677 & $0.000 * * *$ \\
DMU & -10.7744 & 1.2448 & $0.000 * * *$ \\
DIMENSIONS & 14.8091 & 2.1662 & $0.000 * * *$ \\
NON_PARA & 0.7288 & 2.2019 & 0.741 \\
INPUT_ORT & -3.3513 & 1.7175 & 0.052. \\
CRS & -4.9851 & 1.5885 & $0.002 * *$ \\
COUNTRY & -7.3033 & 1.9583 & $0.000 * * *$ \\
\hline
\end{tabular}

Note: Significance codes: $\mathrm{p}<0.1 ; * \mathrm{p}<0.05 ; * * \mathrm{p}<0.01 ; * * * \mathrm{p}<0.001$.

Source: Own elaboration.

We used meta-regression analysis for predicting the average technical efficiency of the Czech and Slovak public HEIs. The Czech higher education system includes 26 public HEIs and the Slovak higher education system includes 20 public HEIs. These figures represent the numbers of units (DMU). The variable DIMENSIONS represents the number of inputs and outputs. We used median of DIMENSIONS from Table 2 for both countries. Since DEA was chosen, the dummy variable NON_PARA assumes the value of 1 . This choice was made because the number of units is small and it is suitable to use a non-parametric method.

We chose the output-oriented model for the variable INPUT_ORT (dummy $=0$ ), since $66 \%$ of all the models in the data set are output-oriented. In line with Kempkes and Pohl (2007), we also believe the particular choice of the model orientation depends on the level of control under which the given university's administrator works.

Higher education institutions in Germany, as well as those in the Czech Republic and Slovakia, are publicly funded and therefore the volume of expenditure, research output or the number of technical staff can also be considered as given. Both constant and variable returns to scale were used for the variable CRS to calculate the scale of efficiency. The Czech Republic and Slovakia are European countries, therefore dummy $=1$ was used for the variable COUNTRY. The predicted average technical efficiency of the Czech and Slovak public HEIs is shown in Table 6. 
T a ble 6

Predicted Average Technical Efficiency of Public Heis

\begin{tabular}{|l|c|c|c|c|}
\hline Country & Sample size & CRS & VRS & Scale effect \\
\hline Czech Republic & 26 & 80.08 & 85.07 & 94.14 \\
Slovakia & 20 & 82.91 & 87.89 & 94.33 \\
\hline
\end{tabular}

Source: Own elaboration.

All the variables (including statistically insignificant variables at the 5\% significance level, i.e. the variables NON_PARA and INPUT_ORT) were used to predict the average technical efficiency of the Czech and Slovak HEIs. The reason being is that Soukup (2010) recommends using confidence intervals instead of statistical significance. He reasons with shortcomings of statistical significance which include insufficient testimony about the basic data set, mechanical work with the classical 5\% significance level, statistical significance not automatically translating into importance, or non-publication of statistically insignificant results. Wassertein, Shirm and Lazar (2019) also deal with this topic and go even further. For example, one of their chapters is called Don't Say "Statistically Significant". Confidence intervals represent the range over which the value of the relevant parameter can fluctuate (Soukup, 2010; see Table 7). Using only "stars" $(*, * *$ and $* * *$ in the p-value column) without considering other information can result in elimination of a variable that actually affects the dependent variable. The problem of reporting and accumulating only statistically significant results (file drawer problem) has been already pointed out by Rosenthal (1979). For example, if meta-analyses only draw conclusions based on the statistically significant results, these results are biased (Soukup, 2010).

T a ble 7

\section{Confidence Intervals}

\begin{tabular}{|l|r|r|}
\hline Variables & $\mathbf{2 . 5} \%$ & $\mathbf{9 7 . 5} \%$ \\
\hline Intercept & 91.5711 & 114.2497 \\
SIZE & -13.2216 & -8.3272 \\
DIMENSION & 10.5504 & 19.0679 \\
NON_PARA & -3.6001 & 5.0577 \\
INPUT_ORT & -6.7279 & 0.0252 \\
CRS & -8.1081 & -1.8620 \\
COUNTRY & -11.1533 & -3.4533 \\
\hline
\end{tabular}

Source: Own elaboration.

When the variables NON_PARA and INPUT_ORT get eliminated, we arrive at slightly different results (see Table 8). Meta-analysis showed that DEA is used more often than SFA. DEA was used in $80 \%$ of the cases in our data set, therefore meta-regression analysis showed the NON_PARA variable as statistically 
insignificant at the 5\% significance level. On the other hand, DEA is more suitable for measuring the efficiency of the Czech and Slovak HEIs than SFA, because the sample size of units (HEIs) is small. And this information should not be overlooked. Elimination of the INPUT_ORT variable has no impact on the predicted values. We used the output-oriented model (INPUT_ORT $=0$ ) and in this case, elimination of this variable has no effect on the result. Elimination of the variable INPUT_ORT is also supported by the research by McMillan and Datta (1998) and Aracil and Montero (2008), who reported that the input-oriented and output-oriented models give similar results.

T a ble 8

Predicted Average Technical Efficiency of Public Heis without Statistically Insignificant Variables

\begin{tabular}{|l|c|c|c|c|}
\hline Country & Sample size & CRS & VRS & Scale effect \\
\hline Czech Republic & 26 & 79.35 & 84.34 & 94.10 \\
Slovakia & 20 & 82.18 & 87.16 & 94.28 \\
\hline
\end{tabular}

Source: Own elaboration.

\section{Conclusion and Final Remarks}

Meta-analysis is a very useful method to summarise existing research and analyse this data. Using this method, we were able to identify the most commonly adopted inputs and outputs in the DEA and SFA models and to construct the regression model for predicting the average technical efficiency of the Czech and Slovak public higher education institutions.

We specify the selection criteria under which the 126 examined studies were chosen. The most adopted input variables were the number of academic staff, number of other employees, volume of operating costs, volume of total expenditure, number of students and number of employees. The most used outputs were the number of graduates, number of students, total number of $\mathrm{PhD}$ degrees awarded, number of grants, number of publications and the volume of grants.

Only 38 studies were suitable for meta-regression analysis. The effect of six independent variables (sample size, number of inputs and outputs, method used, model orientation, returns to scale and the country) on the dependant variable (average technical efficiency) was analysed. Increasing the sample size (DMU) leads to a decrease in the average technical efficiency (EFF). Increasing the number of inputs and outputs (DIMENSIONS) leads to an increase in EFF. The choice of the DEA methodology (NON_PARA) leads to an increase in EFF. The choice of input-orientation (INPUT_ORT), constant returns to scale (CRS) and the European country (COUNTRY) leads to decrease in EFF. 
We used meta-regression model for the predicting the average technical efficiency of the Czech and Slovak public higher education institutions. According to this model, the average efficiency is slightly higher in Slovakia than in the Czech Republic.

Limits of the presented research can be seen in disadvantages of metaanalysis. The use of this method assumes that all the relevant studies, papers and analyses, including those not yet published, are found. Trying to find all such studies would be both time and money consuming, or even impossible.

For further research, we recommend using other economic variables, such as GDP, population density, or the share of public expenditures that flow into public HEIs as a proportion to the total expenditure of the ministry. It would be interesting to analyse whether there is any impact of these economic variables on the technical efficiency of the public HEIs or not.

\section{References}

ABBOTT, M. - DOUCOULIAGOS, C. (2003): The Efficiency of Australian Universities: A Data Envelopment Analysis. Economics of Education Review, 22, No. 1, pp. 89 - 97.

AFONSO, A. - SANTOS, M. (2005): Students and Teachers: A DEA Approach to the Relative Efficiency of Portuguese Public Universities. Lisbon: Technical University of Lisbon, Department of Economics and CISEP - Research Centre on the Portuguese Economy.

AGASISTI, T. (2016): Cost Structure, Productivity and Efficiency of the Italian Public Higher Education Industry 2001 - 2011. International Review of Applied Economics, 30, No. 1, pp. $48-68$.

AGASISTI, T. - GRALKA, S. (2017): The Transient and Persistent Efficiency of Italian and German Universities: A Stochastic Frontier Analysis. [Working Paper, No. 14/17.] Dresden: CEPIE.

AGASISTI, T. - JOHNES, G. (2009): Beyond Frontiers: Comparing the Efficiency of Higher Education Decision-making Units across More than One Country. Education Economics, 17, No. 1 , pp. $59-79$.

AGASISTI, T. - JOHNES, G. (2010): Heterogeneity and the Evaluation of Efficiency: The Case of Italian Universities. Applied Economics, 42, No. 11, pp. 1365 - 1375.

AGASISTI, T. - POHL, C. (2012): Comparing German and Italian Public Universities: Convergence or Divergence in the Higher Education Landscape? Managerial and Decision Economics, 33, No. 2, pp. $71-85$.

AGASISTI, T. - SALERNO, C. (2007): Assessing the Cost Efficiency of Italian Universities. Education Economics, 15, No. 4, pp. 455 - 471.

AGASISTI, T. - WOLSZCZAK-DERLACZ, J. (2014): Exploring Universities' Efficiency Differentials between Countries in a Multi-year Perspective: An Application of Bootstrap DEA and Malmquist Index to Italy and Poland, 2001 - 2011. [Working Paper, No. 113 - 14.] Berkeley: IRLE.

AIGNER, D. - LOVELL, C. - SCHMIDT, P. (1977): Formulation and Estimation of Stochastic Frontier Production Models. Journal of Econometrics, 6, No. 1, pp. 21 - 37.

ARACIL, A. G. - MONTERO, D. P. (2008): Methodological Problems to Measure University Efficiency in Relation with its Geographic Localization. Valencia/Spain: Institute for Innovation and Knowledge Management, INGENIO (CSIC-UPV). 
AVKIRAN, N. K. (2001): Investigating Technical and Scale Efficiencies of Australian Universities through Data Envelopment Analysis. Socio-Economic Planning Sciences, 35, No. 1, pp. 57 - 80.

BALL, C. (1985): What the Hell is Quality? In: BALL, C. and URWIN, D. (ed.): Fitness for Purpose: Essays in Higher Education. Guildford: Society for Research into Higher Education \& NFER-Nelson, pp. 96 - 102.

BANKER, R. D. - CHARNES, A. - COOPER, W. W. (1984): Some Models for Estimating Technical and Scale Inefficiencies in Data Envelopment Analysis. Management Science, 30, No. 9, pp. $1078-1092$.

BARRA, C. - ZOTTI, R. (2014): Handling Negative Data Using Data Envelopment Analysis: A Directional Distance Approach Applied to Higher Education. [MPRA Paper, No. 55570.] Munich: University of Salerno.

BARRA, C. - ZOTTI, R. (2016): A Directional Distance Approach Applied to Higher Education: An Analysis of Teaching-related Output Efficiency. Annals of Public and Cooperative Economics, 87, No. 2, pp. $145-173$.

BATTESE, G. E. - CORRA, G. S. (1977): Estimation of a Production Frontier Model: With Application to the Pastoral Zone of Eastern Australia. Australian Journal of Agricultural Economics, 21, No. 3, p. 11.

CHARNES, A. - COOPER, W. W. - RHODES, E. L. (1978): Measuring the Efficiency of Decision Making Units. European Journal of Operational Research, 6, No. 2, pp. 449 - 444.

COELLI, T. et al. (2005): An Introduction to Efficiency and Productivity Analysis. Second Edition. Springer.

COKGEZEN, M. (2009): Technical Efficiencies of Faculties of Economics in Turkey. Education Economics, 17 , No. 1, pp. 81 - 94.

CUENCA, J. S. (2011): Efficiency of State Universities and Colleges in the Philippines: A Data Envelopment Analysis. [Discussion Paper, Series No. 2011-14.] Makati City: Philippine Institute for Development Studies.

CUNHA, M. - ROCHA, V. (2012): On the Efficiency of Public Higher Education Institutions in Portugal: An Exploratory Study. Porto: The University of Porto.

DAGHBASHYAN, Z. (2011): The Economic Efficiency of Swedish Higher Education Institutions. [CESIS, KTH, Paper, No. 245.] Stockholm: Division of Economics.

FLEGG, A. T. et al. (2004): Measuring the Efficiency of British Universities: A Multi-period Data Envelopment Analysis. Education Economics, 12, No. 3, pp. 231 - 249.

GRALKA, S. (2018): Stochastic Frontier Analysis in Higher Education: A Systematic Review. [CEPIE Working Paper, No. 05/18.] Dresden: Technische Universität Dresden, Faculty of Business and Economics.

GROMOV, A. D. (2017): The Efficiency of Russian Higher Education Institution and its Determinants. [Working Papers, Series: Education, WP BRP 40/EDU/2017.] Moscow: National Research University Higher School of Economics.

HENDL, J. (2012) Přehled statistických metod: Analýza a metaanalýza dat. Edition 4. extended Praha: Portál, p. 736. ISBN 978-80-262-0200-4.

JABLONSKÝ, J. - DLOUHÝ, M. (2004): Modely hodnocení efektivnosti produkčních jednotek. 1. Edition. Praha, Professional Publishing, p. 184. ISBN 80-86419-49-5.

JOHNES, G. et al. (2005): An Exploratory Analysis of the Cost Structure of Higher Education in England. Lancaster: Lancaster University Management School.

JOHNES, J. (2006): Data Envelopment Analysis and Its Application to the Measurement of Efficiency in Higher Education. Economics of Education Review, 25, No. 3, pp. 273 - 288.

KEMPKES, G. - POHL, C. (2007): The Efficiency of German Universities - Some Evidence from Non-Parametric and Parametric Methods. Venice: CESinfo Venice Summer Institute, 18 - 19 July.

KULSHRESHTHA, P. - NAYAK, T. K. (2015): Efficiency of Higher Technical Educational Institutions in India. Archives of Business Research, 3, No. 1, pp. 94 - 122. 
LEE, B. L. (2011): Efficiency of Research Performance of Australian Universities: A Reappraisal using a Bootstrap Truncated Regression Approach. Economic Analysis \& Policy, 41, No. 3, pp. $195-203$.

MALEKI, G. - KLUMPP, M. - CUYPERS, M. (2012): Higher Education Productivity and Quality Modelling with Data Envelopment Analysis Methods. In: KLUMPP, M. (ed.): European Simulation and Modelling Conference. [Conference Proceedings, 22 - 24. 10. 2012.] Essen, Germany: FOM University, pp. $231-233$.

MCMILLAN, M. L. - DATTA, D. (1998): The Relative Efficiencies of Canadian Universities: A DEA Perspective. Canadian Public Policy, 24, No. 4, pp. 485 - 511.

MCMILLAN, M. L. - CHAN, W. H. (2006): University Efficiency: A Comparison and Consolidation of Results from Stochastic and Non-stochastic Methods. Education Economics, 14, No. 1, pp. $1-30$.

MEEUSEN, W. - van den BROECK, J. (1977): Efficiency Estimation from Cobb-Douglas Production Function with Composed Error. International Economic Review, 18, No. 2, pp. 435 - 444.

MONFARED, M. A. S. - SAFI, M. (2011): Efficiency Analysis of Public Universities in Iran Using DEA Approach: Importance of Stakeholder's Perspective. Journal of Industrial and Systems Engineering, 5, No. 4, pp. 185 - 197.

NAZARKO, J. - ŠAPARAUSKAS, J. (2014): Application of DEA Method in Efficiency Evaluation of Public Higher Education Institution. Vilnius: Technological and Economic Development of Economy.

OECD (2018): Education at a Glance: OECD Indicators. Paris: OECD Publishing.

POLOUČEK, S. et al. (2006): Bankovnictví. 1. Edit. Praha: C. H. Beck. ISBN 80-7179-462-7.

R Core Team (2017): R: A Language and Environment for Statistical Computing. Vienna, Austria: R Foundation for Statistical Computing. Available at: 〈https://www.R-project.org/>.

ROBST, J. (1997): Cost Efficiency in Public Higher Education. Binghamton: Department of Economics, SUNY.

ROSENTHAL, R. (1979): The "File Drawer Problem" and the Tolerance for Null Results. Psychological Bulletin, 86, No. 3, pp. $638-641$.

SAV, G. T. (2016): Declining State Funding and Efficiency Effects on Public Higher Education: Government Really Does Matter. Int Adv Econ Res, 22, No. 4, pp. 397 - 408.

SCHINDLER, L. et al. (2015): Definitions of Quality in Higher Education: A Synthesis of the Literature. Higher Learning Research Communications, 5, No. 3, pp. 3 - 13.

SOUKUP, P. (2010): Nesprávná užívání statistické významnosti a jejich možná řešení. Praha: Institut sociálních studií, Fakulta sociálních věd, Univerzita Karlova v Praze.

STEVENS, P. A. (2001): The Determinants of Economic Efficiency in English and Welsh Universities. [Discussion Paper, No. 185.] London: National Institute of Economic and Social Research.

TOCHKOV, K. - NENOVSKY, N. - TOCHKOV, K. (2012): University Efficiency and Public Funding for Higher Education in Bulgaria. Post-Communist Economies, 24, No. 4, pp. 517 - 534.

TRAN, C. D. T. T. - VILLANO, R. A. (2017): Input Rigidities and Performance of Vietnamese Universities. Asian Economic Journal, 31, No. 3, pp. 253 - 273.

WASSERSTEIN, R. L. - SCHIRM, A. - LAZAR, N. A. (2019): Moving to a World Beyond ,p < 0.05“. The American Statistician, 73, No. 1, pp. $1-19$.

ZEILEIS, A. (2004): Econometric Computing with HC and HAC Covariance Matrix Estimators. Journal of Statistical Software, 11, No. 10, pp. $1-17$.

ZHENG, H. Y. - STEWART, A. C. (2002): Assessing the Performance of Public Research Universities Using NSF/NCES Data and Data Envelopment Analysis Technique. AIR Professional File, No. 83.

ZOGHBI, A. C. - ROCHA, F. - MATTOS, E. (2013): Education Production Efficiency: Evidence from Brazilian Universities. Economic Modelling, 31, No. 1, pp. 94 - 103. 


\section{A p pendix}

Table 9

Alphabetical List of Primary Studies Used for Meta-Regression Analysis

\begin{tabular}{|c|c|c|}
\hline Authors & Country & Method \\
\hline Abbott and Doucouliagos (2003) & Australia & DEA \\
\hline Afonso and Santos (2005) & Portugal & DEA \\
\hline Agasisti (2016) & Italy & SFA \\
\hline Agasisti and Gralka (2017) & Italy, Germany & SFA \\
\hline Agasisti and Johnes (2009) & Italy, England & DEA \\
\hline Agasisti and Johnes (2010) & Italy & SFA \\
\hline Agasisti and Pohl (2012) & Italy, Germany & DEA \\
\hline Agasisti and Salerno (2007) & Italy & DEA \\
\hline Agasisti and Wolszczak-Derlacz (2014) & Italy, Poland & DEA \\
\hline Avkiran (2001) & Australia & DEA \\
\hline Barra and Zotti (2014) & Italy & DEA \\
\hline Barra and Zotti (2016) & Italy & DEA \\
\hline Coelli et al. (2005) & Australia & DEA \\
\hline Cokgezen (2009) & Turkey & DEA \\
\hline Cuenca (2011) & Philippines & DEA \\
\hline Cunha and Rocha (2012) & Portugal & DEA \\
\hline Daghbashyan (2011) & Sweden & SFA \\
\hline Flegg et al. (2003) & Great Britain & DEA \\
\hline Flegg et al. (2004) & Great Britain & DEA \\
\hline Gromov (2017) & Russia & DEA \\
\hline Johnes (2006) & England & DEA \\
\hline Johnes et al. (2005) & England & DEA, SFA \\
\hline Kempkes and Pohl (2007) & Germany & DEA, SFA \\
\hline Kulshreshtha and Nayak (2015) & India & DEA, SFA \\
\hline Lee (2011) & Australia & DEA \\
\hline Maleki, Klumpp and Cuypers (2012) & Germany & DEA \\
\hline McMillan and Datta (1998) & Canada & DEA \\
\hline McMillan and Chan (2006) & Canada & DEA, SFA \\
\hline Monfared and Safi (2011) & Iran & DEA \\
\hline Nazarko and Saparaukas (2014) & Poland & DEA \\
\hline Robst (1997) & US & SFA \\
\hline Sav (2012) & US & DEA, SFA \\
\hline Sav (2016) & US & SFA \\
\hline Stevens (2001) & England & SFA \\
\hline Tochkov, Nenovsky and Tochkov (2012) & Bulgaria & DEA \\
\hline Tran and Villano (2017) & Vietnam & DEA \\
\hline Zheng and Stewart (2002) & US & DEA \\
\hline Zoghbi, Rocha and Mattos (2013) & Brazil & SFA \\
\hline
\end{tabular}

Source: Own elaboration. 